capacity of the author's mind. Mr. Gorham, however, is well known among the London entomologists as an acute and highly promising Coleopterist; and we hope he will work up other comparatively neglected families with the same ability he has shown in the brochure before us. We regret to see that in the preface the author complains of difficulties thrown in his way by the authorities of the British Museum. There must have been some misapprehension; Dr. Gray, we believe, is as ready now as formerly to assist any one studying the collections under his charge.

\title{
MISCELLANEOUS.
}

\section{On the Respiratory Organs of the Araneida.}

By Dr. P. BertKad.

THe old division of the Arachnida into pulmonary and trachean, established by Latreille, lost all its value when Léon Dufour, Dugès, and, after them, Menge and Siebold discovered that the Araneida possessed tracheæ besides their lungs.

One might be surprised at first to see two different aërial respi'ratory apparatus existing together in the same animal ; but Leuckart soon showed that the so-called lungs ought to be considered a formation homologous with that of the tracheæ, and he gives them, in consequence, the name of pulmonary tracheæ (Lungentracheen). This interpretation has been generally accepted; and the new observations of M. Bertkau go also to confirm it.

The author describes the structure of the lungs, for which he proposes on his part the name of laminar tracheæ (Fächertracheen) and that of the tracheæ properly so called. From these investigations, which have been directed to a great number of genera and species, he deduces a grouping of Araneida based on the modifications that these animals present in their respiratory organs. We shall not follow him in the description that he gives of the lungs, because it contains nothing but well-known facts. We may reeall only that the two stigmata which admit the air into these organs are situated on the lower surface of the abdomen, immediately behind the peduncle which unites that region to the cephalothorax. In some genera there is behind these pulmonary stigmata, and quite close to them, another pair of stigmata. It is only in the Mygalidæ that these orifices lead, like the anterior ones, to a second pair of lungs. In Dysdera, Segestria, and Argyroneta they give access to a trachean system. A very short canal, starting from each of them, leads to a wide, compressed, principal trunk, of which the wall is strengthened by chitinous rods, which are either irregularly placed (Dysdera) or united into a spiral thread exactly as in the tracheæ of insects (Segestria and Argyroneta). The greater portion of the trachean trunk inclines forward; a little bursiform appendage is directed backward. In Dysdera and Argyroneta each of the two anterior or 
cephalothoracic trunks passes into the cephalothorax, where it terminates in a little rounded swelling, from which issue a considerable number of small unramified tubes with thin walls. In Segestria the trunks remain in the abdomen and do not become inflated ; but they also send forth little tubes of the same nature, which, uniting in two strong bundles, penetrate in great part into the cephalothorax. Each posterior or abdominal trunk gives origin throughout its length to a great number of little tubes going to the organs of the abdomen. These tubes, starting from the trachean trunks, proceed in bundles to the extremities of the appendages, gradually diminishing in size, but without ramifying or presenting anastomoses. No trace of a spiral thread can be detected in them, even under the strongest magnifying-powers. In all the other Araneida there are in front only the two anterior stigmata leading to the lungs. On the other hand, we find at the posterior extremity of the body, and immediately before the spinnerets, a transverse slit formed by the coalescence of a pair of stigmata, and leading to two symmetrically constructed tracheæ. The trachean system, which is connected with these stigmata, presents great differences, aceording to genera. In Dyctina, Sund., it presents the greatest resemblance to that of Dysdera, Segestria, and Argyroneta, and only differs in the smaller number of the tubules. In Erigone, Sav., and Micryphantes, Koch, the trachean system is less developed. The air-sac, which is small, first " gives origin on each side to a simple tube, which terminates in a fine point. Beyond the point of origin of these two tubes the sac is divided into two short, wide, and flattened trunks. From the middle of their length these trunks send forth some tubules, of which some remain in the abdomen, while the others pass into the cephalothorax, where they are distributed even into the extremities.

The genera of the family of the Attidæ have a trachean system constructed on a very uniform plan. It commences by two trunks but little ramified, and sends forth at intervals a great number of bundles of tubules. In the wall of the tubules there are seen transverse lines which seem to indicate the appearance of a spiral thread.

The Thomisidæ have all the trachean apparatus more simplified and less extended. A narrow fissure leads into a small respiratory cavity, from which four branches start. The two lateral branches are smaller than the intermediate ones; but they all send forth along the whole length of their course, which is limited to the abdomen, branches which ramify in their turn, or terminate in a filiform point without being ramified. The trachean system of the other Araneida presents a still less degree of development. A narrow fissure, situated before the spinnerets, leads into a depressed air-cavity, at the anterior extremity of which issue four simple tubes, flattened in the form of ribbons, having no trace of a spiral thread, but, at most, some fine granulations irregularly disseminated in their membrane. Such, at least, is the general arrangement; it presents some variations in the different genera. In certain cases we see the two tubes of each side, which were originally united, bifureate further on; or the two median tubes, at first united, separate beyond the origin of the lateral 
tubes. In general the external tubes are more slender, but longer than the internal ones.

M. Bertkau has in vain sought for these simple tracheæ at the extremity of the abdomen in Oletera, Dysdera, and Segestria.

Thus it is established that the Araneida have four stigmata, of which the two anterior are situated at the anterior part of the abdomen. The two others are placed either immediately behind these or further back, at the extremity of the abdomen. In this latter case they unite to form a fissure in the median line. The first pair of stigmata always leads to "lungs;" the second to lungs (Mygalidx) or, more frequently, to tracheæ. When the second pair of stigmata is anterior, the tracheæ to which it corresponds always present two principal trunks-one directed forward, furnishing trachean tubes to the cephalothorax (Dysdera and Segestria), whilst the other passes backward and supplies the abdomen. When the second pair of stigmata is situated at the extremity of the abdomen, and the two trunks must necessarily go forward, it is the external one which corresponds to the posterior trunk of Dysdera and Segestria.

The modifications which are observed in the respiratory apparatus of the Araneida are in correlation with those which are manifested in the rest of the organization and which have served to establish the principal groups. There are, however, some points on which a division having for base the organization of the respiratory apparatus does not exactly coincide with the classification adopted now. This is observed, for example, in the family of the Thomisidæ, in which the genera Thomisus, Xysticus, Artamus, and Philodromus have ramified trachean tubes, while they are not so in Sparassus and Thanatus. But it must be remarked at the same time that the forms belonging to these two genera differ by their facies, by the claw of their first jaws, and by the claws of the feet. M. Bertkau has therefore established a family of Sparassidæ which forms a transition from the Thomisidæ to the Lycosidæ. Scytodes includes the only known representatives of a new family, that of the Scytodidæ; and Dictyna, Erigone, and Micryphantes constitute the family of the Micryphantidæ, in which, perhaps, we ought to place Argyroneta, a genus of which the place is yet uncertain.

The author proposes the following grouping of the Araneida :-

I. Two pairs of laminar tracheæ. Mygalida (Tetrapneumones).

II. A single pair of laminar tracheæ.

A. A pair of tubular tracheæ in tufts.

a. Stigmata distinct. Dysdera, Argyroneta.

b. Stigmatary aperture common. Micryphande, Attidee.

B. A pair of ramified tubular tracheæ with a common orifice. Thomisida.

C. Four simple tubes with a common orifice. Scytodida, Drassida, Agelenida (excl. Argyroneta), Epeirida, Theridida (in great part), Sparassida, Lycosida.

-Archiv für Naturg. vol. xxxviii. (1872) p. 208; Bibl. Univ. April 15, 1873, Bull. Sci. p. 355. 
Migrations of Danais Archippus.

To the Editors of the Annals and Magazine of Natural History.

Altona, October 15, 1873.

Gentlemen,-In the June and August numbers of the 'Annals' are two letters from Professor F. M'Coy regarding the sudden appearance of Danais Archippus in Australia. I beg to state that I have just published, in the fourth part of the 'Journal des Museum Godeffroy' (Hamburg, L. Friederichsen \& Co.), all the facts known to me on the wandering of this American butterfly over the islands of the Pacific Ocean, and the continent of Australia, to Gorontalo on North Celebes, where Dr. A. B. Meyer captured four specimens of Danais Archippus - three of which are at the Berlin Museum, and one in my collection.

Georg SeMrer.

On the Change of Form of the Lachrymal Pit during Growth in the Skulls of the Bush-boks (Cephalophus) and Muntjacs (Cervulus). By Dr. J. E. Gray, F.R.S.

The lachrymal pit is large, rounded, deep, and well developed in the adult bush-boks; and the characters afforded by these parts have generally been considered important for the separation of the genera and species of the bush-boks and other antelopes; but care should be taken to compare skulls (at least of the species of bush-boks) of nearly the same age. The lachrymal pit of Cephalophus rufilatus, $C$. badius, and $C$. coronatus is large and deep in the adult skull; but in the younger skulls it is smaller and shallower, being least marked of all in the young specimens. It is very slightly marked in the skull of $C$. Whitfieldii and $C$. bicolor, which are only known from very young specimens, and of which we do not know the adult; but the skull will very probably be like that of the adult of other bush-boks.

I think we may conclude, from these facts, that the tear-pit in this genus is small and shallow in the young, and increases in size, form, and depth as the animal approaches the adult age. The variation is so great that it is only safe to compare the skulls of different species of the same or nearly the same age.

The size of the intermaxillary bone appears to be generally a good character, and not influenced by age; but sometimes it varies in extent in different specimens of the same species. In three specimens of Cephalophus Ogilbyi, for example, the intermaxillary bone does not reach the edge of the nasal; but in one specimen the intermaxillary bone is very large, and is margined above by the nasal (Hand-list of Ruminants, t. xxxiii. f. 2). The size of the orbit seems to be pretty permanent in the skulls of the different species.

I have not had the opportunity of observing this change in the skulls of the other genera of antelopes and the allied animals. Perhaps it is not so great as in this group. 


\section{$2 \mathrm{BHL}$ Biodiversity Heritage Library}

Bertkau, Philipp. 1873. "On the respiratory organs of the Araneida." The Annals and magazine of natural history; zoology, botany, and geology 12, 422-425. https://doi.org/10.1080/00222937308680794.

View This Item Online: https://www.biodiversitylibrary.org/item/63347

DOI: https://doi.org/10.1080/00222937308680794

Permalink: https://www.biodiversitylibrary.org/partpdf/58983

\section{Holding Institution}

University of Toronto - Gerstein Science Information Centre

\section{Sponsored by}

University of Toronto

\section{Copyright \& Reuse}

Copyright Status: NOT_IN_COPYRIGHT

This document was created from content at the Biodiversity Heritage Library, the world's largest open access digital library for biodiversity literature and archives. Visit BHL at https://www.biodiversitylibrary.org. 